\title{
Effect of Temperature and Relative Humidity on the Development of Blue Mould Rot (Penicillium islandicum Sopp.) on Indian Gooseberry (Emblica officinalis Goerth.)
}

\author{
Anil Kumar Saini*, Sushil Kumar Sharma, Anil Kumar and Pankaj Kumar
}

Chaudhary Charan Singh Haryana Agricultural University, Hisar, Haryana-125 004, India

*Corresponding author

\section{A B S T R A C T}

\section{Keywords}

Penicillium islandicum, Indian gooseberry,

Temperature,

Relative humidity,

Blue mould rot

Article Info

Accepted:

15 June 2018

Available Online:

10 July 2018
To study the effect of weather parameters i.e. temperature and relative humidity on the development of blue mould rot (Penicillium islandicum Sopp.) on Indian gooseberry in vitro experiment were carried out at Post graduate laboratory, Department of Plant pathology, Chaudhary Charan Singh Haryana Agricultural University, Hisar. An interaction of three temperatures i.e. 10,20 and $30^{\circ} \mathrm{C}$ with relative humidity of $40,60,80$ and $100 \%$ was carried out at five and ten days after inoculation (DAI). Temperature of 30 ${ }^{\circ} \mathrm{C}$ along with cent per cent relative humidity resulted in maximum disease incidence of 87 and $100 \%$ in both 5 and 10 DAI, respectively. Minimum disease intensity (15 and 22\%) was recorded at $10^{\circ} \mathrm{C}$ temperature and 40 per cent relative humidity at 5 and 10 days after inoculation. However, with further increase in temperature and relative humidity, the per cent disease intensity was also increased and it also increased during the period of time (5 and 10 days after inoculation). Thus from the present study, it can be clearly elucidated that low temperature $\left(10^{\circ} \mathrm{C}\right)$ with low relative humidity $(40 \%)$ is ideal for the post harvest storage of Indian gooseberry.

\section{Introduction}

Aonla or Indian gooseberry (Emblica officinalis Goerth. Syn. Phyllanthus emblica L.) is one of the most important indigenous fruit of Indian sub continent (Baghel et al., 2007). It belongs to family Euphorbiaceae and order Euphorbiales. Aonla has been cultivated in India since time immemorial (Singh et al., 2009). It grows in tropical and subtropical parts of India, China, Indonesia and the Malay Peninsula (Golechha et al., 2012 and
Srivasuki, 2012). The area under aonla cultivation in India is about 103.55 thousand hectares and production 1225.21 thousand MT (Anonymous, 2015). Haryana occupies an area of 2226 hectares under this fruit crop with a production of 12056 MT (Anonymous, 2016). Aonla fruit contains different essential nutrients i.e. carbohydrates, proteins, phenol, calcium, phosphorus, zinc, and vitamin B. It is a rich source of vitamin $C$ ranging from 400$1300 \mathrm{mg} / 100 \mathrm{gm}$ pulp and vitamin B 300 mg/100 gm pulp (Singh, 2006; Kore et al., 
2013). Its constituents serve as important source of food and medicine (Kumar and Singh, 2002). It is probably the only fruit to fill the gap of a stringent food recommended in ayurvedic medicine and balanced diet for sound health (Singh, 2006). Alternaria rot, Penicillium mould rot and Aspergillus black mould rot of citrus caused by Alternaria alternata, Penicillium digitatum, Penicillium italicum and Aspergillus niger, respectively have been reported to develop more rapidly at temperature, $15-35^{\circ} \mathrm{C}, 20-25^{\circ} \mathrm{C}$ and $30-35^{\circ} \mathrm{C}$ (Fawcett and Barger, 1927; Agrawal and Hasija, 1967; Bhargava, 1972) respectively. Temperature, ranging from $20-35^{\circ} \mathrm{C}$ is reported to be optimum for the rapid development in case of fruit rot of citrus (Pathak, 1980). Severity of Penicillium and Botryodiplodia rot of sweet orange caused by Penicillium italicum and Botryodiplodia theobromae, respectively have been reported to be highest at 100 per cent relative humidity and lowest at 40 per cent relative humidity (Tandon et al., 1975; Godara, 1994). Gupta and Chauhan (1998) reported effect of temperature on the development of soft rot of Emblica officinalis caused by Penicillium citrinum strains I to VI. They observed that strain VI produced maximum rot $(49.5 \%)$ after 24 days at $25^{\circ} \mathrm{C}$, while at temperatures $15^{\circ} \mathrm{C}, 20^{\circ} \mathrm{C}, 30^{\circ} \mathrm{C}, 35^{\circ} \mathrm{C}$, percentage rot were 17.3, 30.2, 18.3 and 4.8, respectively. Plant diseases including fruit rots were to be more common in humid to wet regions with cool and warm or tropical temperature (Agrios, 2005). The best temperature for growth of Penicillium spp. was found to be $23^{\circ} \mathrm{C}$, and by decreasing the temperature fungal growth decreased (Agostini et al., 2006). Baghel et al., (2008) studied the effect of temperature and relative humidity on fruit rot of aonla caused by Penicillium citrinum. They observed that temperature of $10^{\circ} \mathrm{C}$ was most effective for preservation of aonla as it showed minimum disease severity. However, temperature of 25 and $20^{\circ} \mathrm{C}$ showed maximum disease severity of 87.7 and $71.8 \%$ respectively. They also reported that highest disease severity $(100 \%)$ was observed in the fruits stored at 100 per cent RH. Minimum rotting $(47.1 \%)$ was recorded when fruits were stored at 50 per cent RH.

\section{Materials and Methods}

To evaluate the comparative effect of temperature on disease development, inoculated fruit of aonla were maintained at three different temperatures viz. $10^{\circ} \mathrm{C}, 20^{\circ} \mathrm{C}$ and $30^{\circ} \mathrm{C}$. The inoculation was done by well method. Un-inoculated fruits of the same variety were also maintained at each temperature for comparison. Varying relative humidity levels were maintained with potassium hydroxide solution in sterilized desiccators as suggested by Solomon (1951). The inoculated fruits placed in desiccators were stored at room temperature $25 \pm 2^{0} \mathrm{C}$ for each experiment.

\begin{tabular}{|l|l|}
\hline RH & $\begin{array}{l}\text { KOH gm /200 ml } \\
\text { solution })\end{array}$ \\
\hline $\mathbf{4 0}$ & 75.90 \\
\hline $\mathbf{6 0}$ & 59.00 \\
\hline $\mathbf{8 0}$ & 38.50 \\
\hline $\mathbf{1 0 0}$ & $200 \mathrm{ml}$ distilled water \\
\hline
\end{tabular}

\section{Results and Discussion}

Among the external factors temperature and relative humidity are the most important factors which play a important role in influencing growth rate and other metabolic activities of a pathogen. To study the effect of three varying temperature and four relative humidity ranges, observations on disease intensity of blue mould rot were recorded at 5 and 10 days after inoculation. The fruit pulp was removed to a five $\mathrm{mm}$ depth and then 
inoculated with the disc of culture of the pathogen (7 days old and removed portion was plugged back). Inoculated fruits were placed in desiccators with maintained relative humidity range and incubated at temperature range in B.O.D. Five replications were maintained at $10,20,30^{\circ} \mathrm{C}$ temp. and 40,60 , 80 and 100 per cent RH. levels. Observations for per cent disease intensity were recorded after 5 and 10 days after inoculation. The data presented in Table 1 showed that maximum per cent disease intensity was observed at $30^{\circ} \mathrm{C}$ temperature with 100 per cent relative humidity and minimum at $10^{\circ} \mathrm{C}$ temperature with 40 per cent relative humidity. However, with further increase in temperature and relative humidity, the per cent disease intensity was also increased and it also increased during the period of time (5 and 10 days after inoculation). The data clearly showed the disease intensity differed significantly with days after inoculation at all temperatures and humidity levels. A temperature range of 25 to $30^{\circ} \mathrm{C}$ and humidity levels of 80 to 100 per cent was observed optimum for maximum infection. A variation on either side significantly reduced the disease. Temperature and relative humidity play a vital role in the development of the post harvest diseases. The per cent disease intensity of aonla varied significantly, when it was stored at different temperature with different relative humidity combinations. Temperature of $10^{\circ} \mathrm{C}$ with 40 per cent $\mathrm{RH}$ was most effective for preservation of aonla as it contracted minimum disease intensity $(15 \%)$. However, temperature of $30^{\circ} \mathrm{C}$ with 100 and 80 per cent RH showed maximum per cent disease intensity respectively. The complete decay of aonla fruits was observed at 100 per cent relative humidity with $30^{\circ} \mathrm{C}$ temperature. The present investigations were very close to the observations of Singh and Sumbali (2007) on Penicillium apple rot, Singh and Mandal (2007) on peach fruit rot and Baghel et al., (2008) on aonla.

Table.1 Effect of temperature and relative humidity on the development of blue mould rot on aonla

\begin{tabular}{|c|c|c|c|c|c|c|}
\hline \multirow{3}{*}{$\begin{array}{l}\text { Relative } \\
\text { Humidity }(\%)\end{array}$} & \multicolumn{6}{|c|}{ Disease intensity (\%) } \\
\hline & \multicolumn{3}{|c|}{5 DAI $* *$} & \multicolumn{3}{|c|}{10 DAI } \\
\hline & 10 & 20 & 30 & 10 & 20 & 30 \\
\hline 40 & $\begin{array}{c}15^{*} \\
(22.76)^{* * *}\end{array}$ & $\begin{array}{c}22 \\
(27.94)\end{array}$ & $\begin{array}{c}35 \\
(36.25)\end{array}$ & $\begin{array}{c}22 \\
(27.94)\end{array}$ & $\begin{array}{c}30 \\
(33.16)\end{array}$ & $\begin{array}{c}50 \\
(44.98)\end{array}$ \\
\hline 60 & $\begin{array}{c}25 \\
(29.97)\end{array}$ & $\begin{array}{c}35 \\
(36.25)\end{array}$ & $\begin{array}{c}48 \\
(43.84)\end{array}$ & $\begin{array}{c}30 \\
(33.19)\end{array}$ & $\begin{array}{c}40 \\
(39.21)\end{array}$ & $\begin{array}{c}65 \\
(53.72)\end{array}$ \\
\hline 80 & $\begin{array}{c}35 \\
(36.25)\end{array}$ & $\begin{array}{c}55 \\
(47.85)\end{array}$ & $\begin{array}{c}70 \\
(56.77)\end{array}$ & $\begin{array}{c}42 \\
(40.38)\end{array}$ & $\begin{array}{c}65 \\
(53.72)\end{array}$ & $\begin{array}{c}88 \\
(69.74)\end{array}$ \\
\hline 100 & $\begin{array}{c}38 \\
(38.04)\end{array}$ & $\begin{array}{c}60 \\
(50.75)\end{array}$ & $\begin{array}{c}87 \\
(68.42)\end{array}$ & $\begin{array}{c}47 \\
(43.26)\end{array}$ & $\begin{array}{c}70 \\
(56.78)\end{array}$ & $\begin{array}{c}100 \\
(89.39)\end{array}$ \\
\hline CD (p=0.05) DAI & & & $0.4 \varepsilon$ & & & \\
\hline Temperature & & & $0.5 \mathrm{~s}$ & & & \\
\hline Relative humidity & & & 0.68 & & & \\
\hline
\end{tabular}

*Average of five replications

**Days after inoculation

***Figure in parentheses are angular transformed value 
In conclusion, blue mould rot disease intensity was checked when the fruits were stored at temperature of $10^{\circ} \mathrm{C}$ with 40 per cent relative humidity. However, the most favourable temperature and relative humidity for the blue mould rot was noted at $30^{\circ} \mathrm{C}$ and 100 per cent relative humidity respectively.

\section{References}

Agostini, G. P., Mackenzie, S. J. and Adaskaveg, J. E. 2006. Effect of fungicides and storage conditions on post harvest development of citrus black spot and survival of Guignardia citricarpa in fruit tissues. Plant Disease. 90: 1419-1424.

Agrawal, G. P. and Hasija, S. K. 1967. Alternaria rot of citrus fruits. Indian Phytopathology. 20: 259-260.

Agrios, N. G. 2005. Plant Pathology, 5th ed., Elsevier-Academic Press. p. 635.

Anonymous. 2015. Indian horticulture database 2014. http/www.nhb.gov.in.

Anonymous. 2016. Statistical data. Horticulture Department, Haryana.

Baghel, A., Dantre, R. K. and Verma, K. P. 2007. Effect of non conventional chemical on the fruit rot of aonla caused by Penicillium citrinum Thom. Pestology. 31: 58-59.

Baghel, A., Dantre, R. K. and Verma, K. P. 2008. Effect of temperature and relative humidity on fruit rot of aonla caused by Penicillium citrinum. Annals of Plant Protection Sciences. 16(2): 485-547.

Bhargava, S. N. 1972. Aspergillus rot on Citrus aurentifloia fruits in market. Plant Disease Reporter. 56-64.

Fawcett, H. S. and Barger, W. R. 1927. Relation of temperature to growth of Penicillium italicum and $P$. digitatum and to the citrus fruit decay produced by these fungi. Journal of Agricultural Research. 35: 925-931.
Godara, S.L. 1994. Studies on post harvest diseases of orange fruits. Department of Plant Pathology, Rajasthan College of Agriculture, R. A. U., Bikaner, pp. 192.

Golechha, M., Bhatia, J. and Arya, D. S. 2012. Studies on effects of Emblica officinalis (Amla) on oxidative stress and cholinergic function in scopolamine induced amnesia in mice. Journal of Environmental Biology. 33: 95-100.

Gupta, A. K. and Chauhan, S. 1998. Evaluation of Penicillium citrinum strain for their pathogenicity to ambla fruits. Indian Phytopathology. 51(2): 201-202.

Kore, V.T., Devi, H. L. and Kabir, J. 2013. Packaging, storage and value addition of aonla an under utilized fruit in India. Fruits. 68: 169-173.

Kumar, S. and Singh, I. S. 2002. Physiochemical studies of various cultivars of aonla fruits. Progressive Horticulture. 34(1): 102-104.

Pathak, V. N. 1980. Diseases of fruit crops. Oxford and IBH Publicity Co. New Delhi. pp. 106-111.

Singh, B. P. 2006. Scientific storage of nutritious aonla. Phal-Phool. (Sept.Oct.): 8-10.

Singh, D. and Mandal, G. 2007. Incidence of mycoflora and fruit rotting on peach opening in packaging materials. Annals of Plant Protection Sciences. 15: 161-165

Singh, S., Singh, A. K., Joshi, H. K., Bagle, B. G. and Dhandar, D. G. 2009. Evaluation of packages for transportation and storability on aonla (Emblica officinalis Gaertn.) under semi arid environment of western India. Journal of Food Science and Technology. 46: 127-131.

Singh, Y. S. and Sumbali, G. 2007. Management of Penicillium expansum 
rot of apples by lactic acids bacteria. Annals of Plant Protection Sciences. 15: 399-401.

Solomon, M. E. 1951. Cotrol of humidity with potassium hydroxide, sulphuric acid and other solutions. Bulletin of Entomological Research. 42: 543-554.
Srivasuki, K. P. 2012 Nutritional and health care benefits of Amla. Journal of Pharmacognosy. 3: 147- 151.

Tandon, M. P., Jamaluddin and Bhargava, V. 1975. Some new fruit rot diseases. Indian Phytopathology 28: 571-572.

\section{How to cite this article:}

Anil Kumar Saini, Sushil Kumar Sharma, Anil Kumar and Pankaj Kumar 2018. Effect of Temperature and Relative Humidity on the Development of Blue Mould Rot (Penicillium islandicum Sopp.) on Indian Gooseberry (Emblica officinalis Goerth.). Int.J.Curr.Microbiol.App.Sci. 7(07): 1889-1893. doi: https://doi.org/10.20546/ijcmas.2018.707.224 